\title{
Strategic municipal real estate management
}

\author{
Maria Trojanek \\ Poznan University of Economics, \\ Poznan, Poland \\ mariatrojanek@wp.pl
}

Abstract. This paper explores the legitimacy of strategic management within municipal real estate stock. It defines the purposes, specificity, and legal and economic aspects of public real estate management. The arguments for changing the current municipal real estate stock management model have been substantiated. We reinforce the thesis that what constitutes the foundation of effective public real estate management is task-based classification of real estate (the purposes that real estate stock serves now and in the future) and the needs resulting from strategic documents. The paper also describes the activities taken up at each stage of the formulation of a strategic management concept.

Keywords: Real estate management, real estate management objectives, real estate management strategy

JEL Classification: L85, B41, P2

\section{INTRODUCTION}

Changes in real estate management in the public sector in free market economies, in which the real estate market developed in a gradual, evolutionary manner, took place at the turn of the 1970s and the 1980s.

They resulted from the following needs:

- cost rationalisation of stock maintenance,

- professionalisation of real estate management,

- to distinguish between the responsibilities of the usufructuary and the owner, and

- to increase the management efficiency of the assets.

Similar phenomena, but of a different scale and scope of occurrence, appear in countries where political and economic system changes are still taking place, including Poland. In countries in which local governments have been restored, changes are additionally determined by:

- a departure from the dominant role and significance of state ownership in the economy,

- increased perception of public property as assets generating financial benefits,

- implementation of free market principles in real estate management, and

- a position change of the public entity from a service and public goods provider to a partner and a regulator of the 'public entity - usufructuary' relationship (Kaganova, Nayyar-Stone 2000). 
This paper presents the specificity of real estate management in municipalities, and indicates the need for a strategic approach in managing the assets.

\section{LEGAL AND ECONOMIC ASPECTS OF REAL ESTATE MANAGEMENT}

The Polish Real Estate Management Act (REMA) (Arts. 23, 25, 25b, and 25d) does not define the term 'management', but enumerates the activities undertaken within property stock management by the State Treasury, communes, districts, and provinces, respectively. These provisions of REMA do not apply to land designated for agricultural and forest purposes, as well as to special-purpose property and premises constituting separate property in a building. Real estate management issues of this type were regulated by separate acts, a list of which is provided by Art. 2.

An analysis of the provisions of REMA reveals that State Treasury real estate management (Art. 23.1) includes legal procedures and factual actions, in particular:

- registration of property according to property cadastre (land and buildings registration);

- ensuring property pricing in stock;

- drawing up stock exploitation plans;

- protecting property from damage and destruction;

- conducting activities connected with the calculation of charges for the property made available from the stock, and conducting recovery of these charges;

- cooperation with other organs which administer, under the provisions of other regulations, State Treasury property, and with due units of local government;

- acquisition and purchase of property constituting stock with the consent of, respectively: province governor, commune council, district council, province Sejmik (council);

- leasing, renting and lending of real estate which is part of the stock. If a contract is concluded for a fixed period longer than three years or for an indefinite period, the province governor's consent is required. The province governor's consent is also required when, following a contract concluded for a fixed period of up to three years, the parties conclude further contracts relating to the same real estate;

- taking legal action, in particular in cases concerning ownership rights or other rights in immovable properties, to obtain receivables for using the real estate, to obtain receivables for tenancy, lease or lending, to confirm inheritance acquisition, or to confirm the ownership rights acquisition of real estate through acquisitive prescription; and

- submitting applications to establish a Land and Mortgage Register for real estate of the State Treasury, local governments units, and submitting applications to make a record in the Land and Mortgage Register.

Municipal real estate stock management consists, in particular (25.2), in performing the above mentioned activities, and:

- preparing geodetic-legal and design developments,

- conducting real estate parcelling and reparcelling, and

- installing (where possible) indispensible technical infrastructure facilities.

As defined by economical science, management is a process of making a choice (making decisions) determined by, on the one hand, people's unlimited needs, and on the other, by limited possibilities (economic stock) according to the criterion of optimising benefits which result from decision making (Wilczyński 1965; Taylor 1975; Czaja, Becla 2007; Czarny 2011; Kudłacz 2013; Krugman, Wells 2013). 
Human needs drive all forms of human activity, including economic and social activities. The type and scale (growth) of human needs is in line with the achieved level of social-economic and civilisational development. Once a higher level of economic, social, and cultural development has been achieved, new needs, previously unidentified, arise. These new needs are accompanied by new and better possibilities of meeting them; however, these possibilities are always limited (Wiszniewski 1977; Szczepański 1981).

Stock limitation (scarcity) is a reflection of the disproportion between the demand for goods and services and their availability (Becla, Czaja, Zielińska 2012). Stock (labour, capital, land) limitation determines the necessity of making choices among different possibilities of using stock in order to satisfy competing needs. Those choices, irrespective of the entity which makes decisions, concern in particular:

- what type of goods to make and what services to provide, and in what quantities,

- how to make (by what means) and what stock to engage,

- who is the target consumer of the goods and services, and

- the hierarchy and chronology of meeting the needs.

This means that in the management process a choice is made among:

- different, unlimited goals of different entities,

- given limited stock, having a multitude of applications, and

- taking into account a different hierarchy and validity of objectives for a particular entity in time.

In summary, management is an intentional activity of (private and public) entities concerning the distribution (engagement) of limited economic stock between different competing applications considered reasonable (i.e. actions compatible with objectives on the basis of a conscious process of calculating results and expenditures).

Thus, real estate management may be read as a process of taking action in the real and legal sphere by (public and private) entities with respect to real estate, focused on choosing the most beneficial solution from among the considered options from the point of view of established objectives.

\section{REAL ESTATE MANAGEMENT OBJECTIVES IN COMMUNES}

The main objective of managing real estate owned by a commune is to effectively use communal real estate in the process of performing public tasks by the commune, i.e. meeting collective needs of the community by providing local public goods. Specific objectives of managing real estate differ depending on the functions performed by the real estate. Municipal real estate may serve to:

- implement the commune's statutory obligations (functions of an administrative and public utility character);

- generate one-off or periodical revenue streams (sales), e.g. rent, lease, lending; or

- implement investment projects or build up a reserve for the implementation of development objectives in the future (Trojanek 1997).

Another area of real estate management in the commune involves activities concerning real estate located within the commune's borders that is the property of another entity. The commune's activities in this respect are of an indirect character, as opposed to managing the real estate which belongs to the commune. In such a case, the commune assumes the role of a local host of the land, the subject of land-use and local development policies, while real estate management is one of the elements of an integrated and consistent development policy.

The purpose of real estate management focused on this type of real estate stock is to form and develop local space in accordance with system development objectives defined in the commune's development strat- 
egy. It also includes study of the conditions and directions for land planning in the municipal area so as to ensure optimal functioning of the local social-economic system, in accordance with sustainable development principles.

A synthetic presentation of the qualities describing the similarities and differences of managing public and private real estate is illustrated in Table1.

Table 1

The substance of managing public and private real estate - similarities and differences

\begin{tabular}{|c|c|c|}
\hline Comparative criteria & Public & Private \\
\hline Management facility & $\begin{array}{l}\text { Public real estate } \\
\text { Private real estate - indirectly }\end{array}$ & Private real estate \\
\hline $\begin{array}{l}\text { Management framework (provisions } \\
\text { of the law and procedures) }\end{array}$ & $\begin{array}{l}\text { Provisions of the law } \\
\text { Commonly abiding } \\
\text { Special, taking into account the real } \\
\text { estate designation - various regula- } \\
\text { tions }\end{array}$ & $\begin{array}{l}\text { Provisions of the law of common } \\
\text { (universal) character - the Civil Code, } \\
\text { the Construction Law, the Property } \\
\text { Management Act, the Spatial Planning } \\
\text { and Development Act }\end{array}$ \\
\hline Management objectives & $\begin{array}{l}\text { Various in terms of the functions per- } \\
\text { formed by real estate in the implemen- } \\
\text { tation of statutory tasks }\end{array}$ & $\begin{array}{l}\text { Various, depending on the broadly de- } \\
\text { fined needs of the owner, both current } \\
\text { and investment, and (often) aspiration } \\
\text { - the desire to be respected }\end{array}$ \\
\hline $\begin{array}{l}\text { The basic principle of making deci- } \\
\text { sions }\end{array}$ & $\begin{array}{l}\text { To achieve the established goal (utility } \\
\text { effect) with minimal stock engage- } \\
\text { ment - the effective use of stock } \\
\text { principle }\end{array}$ & $\begin{array}{l}\text { Achieve maximum effect with avail- } \\
\text { able resources }\end{array}$ \\
\hline Structure of real estate by type & $\begin{array}{l}\text { Diversified due to the functions per- } \\
\text { formed by the real estate and the scale } \\
\text { (stock value) }\end{array}$ & $\begin{array}{l}\text { Usually uniform designation, and } \\
\text { smaller stock }\end{array}$ \\
\hline Main objective of management & $\begin{array}{l}\text { To create a basis for the implementa- } \\
\text { tion of statutory tasks (tasks of public } \\
\text { utility character) }\end{array}$ & To satisfy the owner's needs \\
\hline Managing entity & $\begin{array}{l}\text { The owner of the real estate is a public } \\
\text { entity, while a competent authority } \\
\text { manages it on its behalf and for the } \\
\text { benefit of society }\end{array}$ & Property owner \\
\hline
\end{tabular}

Source: The author's own work.

The need to manage real estate concerns all types of real estate, irrespective of whether the owner is a public entity or a private entity. Public real estate management ought to be efficient (i.e. actions taken in real estate management ought to contribute to the implementation of the priorities of the managing entities and to the achievement of their objectives) and effective (i.e. actions ought to, in the case of private entities, ensure the most favourable ratio of the expected effects to the expenditures incurred, or to ensure the implementation of particular tasks at minimised expenditures, in the case of public entities) (Kieżun, Kubin 2004; Kisiel 2005; Dudycz 2006; Grzymała 2010; Kuciński 2010; Becla, Czaja, Zielińska 2012; Strąk 2012; Umiński 2012; Kieżun 2013; Stawasz 2013; Zielińska 2013). 


\section{ACTIONS TAKEN WITHIN THE REAL ESTATE MANAGEMENT PROCESS}

The theory and experience of real estate management (with respect to the countries where the real estate market is considered to be developed or still developing), the existing body of literature (as has been discussed before) and the conducted research show that until the late 1980s, municipal real estate management was of a reactive character, i.e. the actions taken were in response to usufructuaries' needs. Communes focused their activity on technical and operational aspects of the property rather than on its strategic dimension. The most important reasons for this were as follows:

- high diversity of the portfolio (stock) of the property,

- high fragmentation of real estate management,

- lack of strategic real estate management in communes (towns),

- dispersed responsibility for real estate management. Real estate 'was' a subject of interest of different departments responsible for a particular area of activity,

- lack of consistency and communication between departments making decisions about real estate,

- ineffective real estate management (Zimmerman 2008; Kaganova, McKellar 2006), which did not only concern poor countries (Kaganova, Nayyar-Stone 2000; Van der Schaff 2000; Raport Sveriges Kommuneroch Landsting 2008; Grover 2008).

Similar problems with municipal real estate management also occur in Polish communes (Brol 2004; Brol 2010; Brzeski, Jurek, Szczawińska 2005; Wojciechowski 2012).

Obviously, there is no one universal management model. It is determined by a great number of factors, including, among others:

- political factors,

- cultural factors,

- local factors, and

- managerial skills (Vermiligio 2011).

These factors ensure that changes in municipal real estate management in different countries occur at a different pace and scope. The changes are introduced (forced) in the case of:

- the need to increase the quality of service provided by communes,

- socio-economic changes,

- limited financial resources, and

- budget limitations, rather than usufractuaries' expectations, acting as the catalyst for change in real estate management.

Changes in public real estate management are a result,of the departure from the assumptions of the welfare state in favour of entrepreneurship culture based on efficiency and effectiveness. Taking into account the origin of changes, we may distinguish between top-down transformation (e.g. Great Britain, New Zealand, Australia, and also Eastern Europe countries) and bottom-up transformation (e.g. the United States).

The abovementioned factors determine practical solutions for real estate management in particular countries. Irrespective of those distinguishing factors, it is also possible to point to certain general determinants of a universal character which contribute to the increase in management effectiveness. These include, in particular:

- keeping the register of public property,

- classification of property from the point of view of the functions it performs in the process of the implementation of the communes' tasks,

- detailed description of property, including the determination of the book and market value of a property, 
- development of measurement criteria of management effectiveness with regard to particular types of property,

- cost measurement and the monitoring of the effects of particular types of property,

- setting out standards in terms of the costs incurred and effects achieved, and

- comparison to so-called 'benchmarks' (Grubisic, Nusiovic, Roje 2009; Statlev, Daskalova, Constantin, Raleva, Goschin 2012). A subject of such comparison may be a similar property in the public sector, or a property within the stock of a given entity.

Both in the private sector (earlier) and in the public sector, the approach to real estate as an asset has been redefined. Property is increasingly perceived as strategic stock, indispensible to achieve the organisation's objectives.

Traditionally, municipal real estate has been the commune's material base to implement its statutory tasks. It is also increasingly perceived as an instrument of stimulating local development (impact on private entities' investment decisions) and the opportunity to raise financial resources from the capital market.

A real estate management strategy ought to be in line (consistent) with the strategic objectives of local governments, as stated in the abovementioned strategy documents and documents of an operational character (e.g. local spatial development plans). Management objectives, decision-making criteria, and the role of property in the commune's tasks implementation process are varied. Hence, the basis for the process of managing municipal real estate ought to be task-based classification of real estate (now and in the future) and the needs arising from strategy documents.

It appears that the following categories of real estate are the most effective:

- statutory real estate,

- profit-making real estate, and

- instrumental real estate.

Different options, ways, methods and forms of using each category are possible. Local governments ought to determine the rules (different for each of the distinguished groups, taking into account the adopted priorities of local development strategies) for purchasing and selling municipal real estate.

The classification of real estate into a particular category ought to be conducted from the point of view of its usefulness in the process of implementing the commune's tasks (statutory and others) in a dynamic approach. This requires monitoring usefulness and making decisions about the property's designation in accordance with changes occurring in development forming mechanisms.

Real estate classification requires knowledge about the stock's size and structure, giving rise to the need for stocktaking and recording changes. As part of these activities, there is the need for describing the state of a property, integrating various data (record, legal, technical and economic-financial), not only for accounting purposes, but also for the sake of applying them in the processes of managing those assets.

In the management process, it is essential to know-apart from its size and structure-the stock's book value, but first of all its market value. Therefore, when assessing the efficiency of actions taken, it is crucial to collect market data and information on changes in the local real estate market. The analysis ought to concern those real estate market segments which generate or may possibly generate income in the future (land designated for commercial real estate, land for housing, accommodation stock, facilities to let), and, in particular, the amounts obtained from sales of similar real estate, rent or lease rates.

Apart from income generated by the real estate, periodical result assessment of real estate management should also take into account operational costs connected with the maintenance and exploitation of the property and the costs of necessary repairs and modernization. As regards functional real estate, a decrease in exploitation costs (with the same scope and level of service provided) demonstrates an improvement of this 
ratio. Likewise, an increase in obtained income (e.g. from lease or rent) plays a major role in improving this ratio for profit-making real estate.

Another stage in the process of municipal real estate management is the assessment of needs arising from documents of strategic importance. This assessment ought to provide a basis for making proper decisions concerning:

- purchasing real estate from the commune's stock,

- making real estate available to other entities on a temporary basis,

- sales of redundant real estate, and

- taking development actions concerning developed property (e.g. extension, modernization, repairs, etc).

To sum up, the model process of developing a municipal real estate management strategy includes activities which may be put in stages comprising certain activities. Those activities lead to the recognition and assessment of the existing situation as regards real estate management. They provide a basis for formulating management objectives, developing detailed programmes and tasks concerning groups of real estate arising from the adopted strategy documents, together with the identification of financial abilities and the preparation of the implementation schedule (objectives, priorities, programmes).

Taking into account literature output and the author's own reflections on the discussed issues, we propose the following activities within the process of developing and implementing municipal real estate management strategy (Figure 1).

Strategy implementation:

- Determining the entity responsible for strategy implementation

- Determining instruments

- The monitoring of efficiency and effectiveness

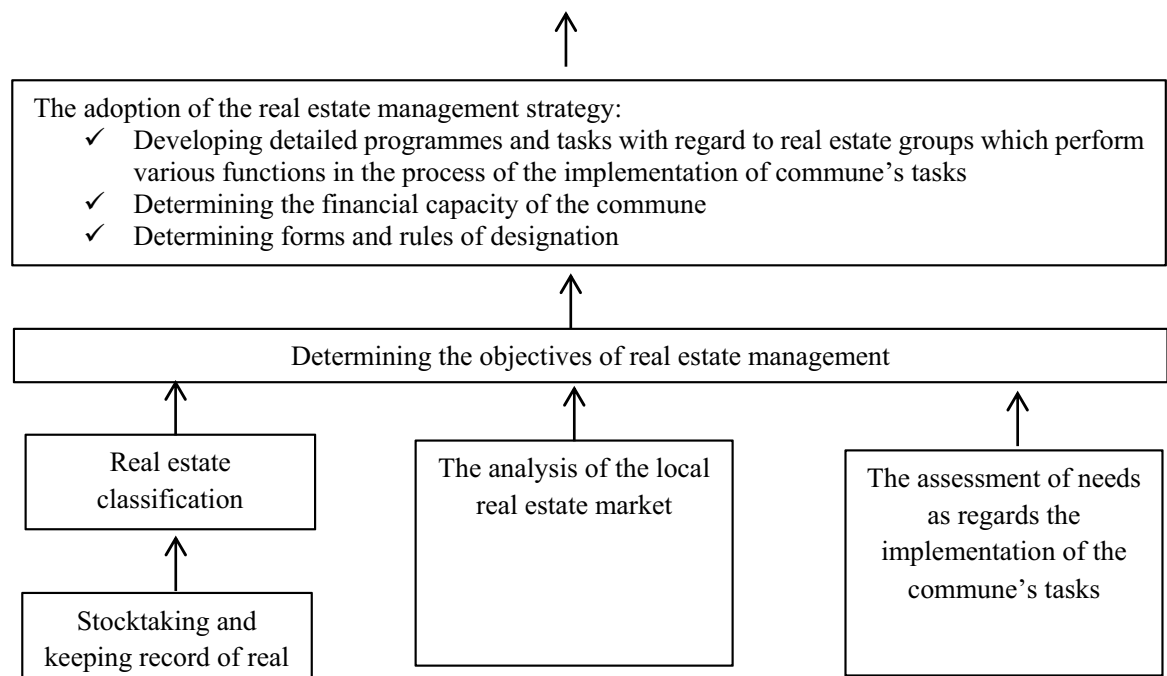

Figure 1. Stages of the development and implementation of municipal real estate management strategy (programme) Source: Author's own work on the basis of (Bogucki, 2005; Filipiak, 2011; Wartalska, 2004;

Dziworska \& Trojanowski, 2008). 
Real estate management results in particular communes vary on account of their scope and scale, depending on the objectives set in strategy documents or sector programmes, local real estate management policies (active or passive) or the instruments applied (planning or implementation).

\section{CONCLUSION}

Due to the limited scope of this paper, we focus only on some selected aspects of municipal real estate management. Considering the legal and economic aspects of municipal real estate management, stock management objectives and functions performed by the stock in the process of the implementation of the commune's tasks, the legitimacy of a strategic approach to real estate management has been substantiated.

The theory and practice of real estate management shows that there is no universal management model. The indications of ongoing changes in the approach to real estate management arise in particular from the need to rationalise the maintenance costs of the stock, the ongoing changes in the size and structure of the stock, or the need to increase management effectiveness of the stock. Not only is municipal real estate a material base for the implementation of the commune's statutory tasks, but it is/may be also an instrument stimulating local development, and it makes it possible to obtain financial resources from the capital market. Hence, it must be considered necessary to give municipal real estate management a strategic dimension.

\section{REFERENCES}

Act on Real Estate Management of 21 August 1997, Journal of Laws of 1997, no. 215, item 741.

Becla, A., P. Czaja, P., A. Zielińska A., (2012), Analiza kosztów korzyści w wycenie środowiska przyrodniczego, Difin, Warsaw: Difin, 2012.

Cymerman, J., (2009), System optat od nieruchomości, Olsztyn, 2009: Educaterra.

Czaja, P., A. Becla, A., (2007), Ekologiczne podstawy procesów gospodarowania, wyd. Akademii Ekonomicznej, Wrocław, 2007: wyd. Akademii Ekonomicznej.

Czarny, B., (2011), Podstawy ekonomii, PWE, Warsaw: PWE, 2011.

Dudycz, T. (ed.), (2006), Efektywność źródtem bogactwa narodów, Wyd. Społeczna Wyższa Szkoła Przedsiębiorczości i Zarządzania, Łódź: Wyd. Społeczna Wyższa Szkoła Przedsiębiorczości i Zarządzania, vol. VII, bull. 1b, 2006.

Dziworska, K., D. Trojanowski, D. (2008), Podstawy strategii zarzadzania nieruchomościami komunalnymi, [in:] Inwestycje i nieruchomości. Wybrane problemy. Fundacja Rozwoju Uniwersytetu Gdańskiego, Sopot: Fundacja Rozwoju Uniwersytetu Gdańskiego, 2008.

Filipiak, B., (2011), Finanse samorzadowe. Nowe wyzwania bieżace i perspektywiczne, Difin, 2011, Warsaw: Difin.

Grover, R., (2008), State and Land Management: The Drivers of Change, FIG, Verona: FIG2008.

Grubisic, M., M. Nusiovic, M., Roje, G. Roje, (2009), Towards Efficient Public Sector Asset Management, Financial Theory and Practice, vol. 33, no. 3, 2009, pp. 329-362.

Grzymała, Z., (2010), Restrukturyzacja sektora komunalnego w Polsce, Warsaw: Oficyna Wydawnicza SGH, Warsaw, 2010.

Kaganova, O., Nayyar-Stone, R. Nayyar-Stone, (2000), Municipal Real Property Asset Management. An Overview of World Experience, Journal of Real Estate, Portfolio Management, Vol. 6, Nr No 4, pp. 307-326.2000.

Kasperowicz, R., Trojanek, R., Cyclical Fluctuations of Residentail Market in Wroctaw, Economics and Sociology, Vol. 3, No 2, 2010, pp. 78-85

Kieżun, W., (2013), Patologia transformacji, Poltext, Warsaw: Poltext, 2013.

Kieżun, W., J. Kubin, J., (2004), Dobre państwo, Warsaw: wyd. Wyższej Szkoły Przedsiębiorczości i Zarządzania im. Leona Koźmińskiego, 2004. 
Kisiel, J., (2005), Problemy zarzadzania nieruchomościami, [in:] Brol, R., (red.), Gospodarka lokalna i regionalna w teorii i praktyce, Wydawnictwo AE we Wrocławiu, Wrocław: Wydawnictwo AE we Wrocławiu, 2005.

Krugman, P., R. Wells, R., (2013), Mikroekonomia, Wydawnictwo Naukowe PWN, Warsaw: Wydawnictwo Naukowe PWN, 2013.

Kuciński, K., (2010) Metodologia nauk ekonomicznych. Dylematy i wyzwania, Warsaw: wyd. Difin, Warsaw, 2010.

Kudłacz, T., (2013), Finansowe aspekty polityki przestrzennej samorządów terytorialnych, [in:] A. Nowakowska, A., A. (ered.), Zrozumieć terytorium. Idea i praktyka, Wydawnictwo Uniwersytetu Łódzkiego, Łódź: Wydawnictwo Uniwersytetu Łódzkiego, 2013.

Marciniak, P. (ed.), (2013), Makro - i mikroekonomia. Podstawowe problemy wspótczesności, PWN, Warsaw: PWN2013.

Municipal real estate. Comparing public real estate management in European cities. Deloitte EMEA, 2011.

Nalepka, A., (2012), Efekty gospodarowania gminnym zasobem nieruchomości i możliwości ich powiększania, [in:] Dudycz, T., Osbert-Pociecha, G., Barycz, B., Efektywność- konceptualizacja i uwarunkowania, wyd. UE Wrocław, Wrocław: wyd. UE Wrocław, 2012.

Proniewicz, J., Szczepańska, K. (ed.), (2005), Efektywna polityka i administracja. Strategie i instrumenty zarządzania miastami,; Poznań: Związek Miast Polskich i Österreichische Städtebund, Bogucki Wydawnictwo Naukowe, 2005.

Raport Sveriges Kommuneroch Landsting, Stockholm 2008.

Statlev P., T. Daskalova T., Constantin D. L., P. Raleva P., Z. Goschin Z., (2012) Development of a Comprehensive System for Municipal Real Property Classification, Administation and Public Management, vol. 19, pp. 17-422012.

Stawasz, D., (2013), Sprawność zarządzania rozwojem terytorium w polskich uwarunkowaniach, w in: Nowakowska, A., (red.), Zrozumieć terytorium. Idea i praktyka, Wydawnictwo Uniwersytetu Łódzkiego, Łódź: Wydawnictwo Uniwersytetu Łódzkiego, 2013.

Strąk, T., (2012), Modele dokonań jednostek sektora finansów publicznych, wyd. Difin, Warsaw: wyd. Difin, 2012.

Szczepański, J., (1981), Konsumpcja a rozwój cztowieka. Wstęp do antropologicznej teorii konsumpcji., PWE, Warsaw 1981. Taylor, E., (1957), Historia rozwoju ekonomiki, PWN, vol. 1, PWN, Warsaw: PWN, 1957.

Trojanek M., Methodic of Estate Valuation in Poland - Actual Status, Economics and Sociology, Vol. 3, No 1, 2010, pp. 66-75.

Trojanek, M., (1997), Podatki i optaty związane z nieruchomościami jako jedno ze źródet dochodów gmin, Zeszyty Naukowe WSB w Poznaniu, no. 1-2, 1997.

Trojanek, R., Dwelling's Price Fluctuations and the Business Cycle, Economics and Sociology, Vol. 3, No 2, 2010 , pp. 67-77.

Umiński, P., (2012) Rozważania nad natura, przyczynami oraz konkurencyjnością dziatalności eksportowej w ujęciu regionalnym dla Polski, Gdańsk: Wydawnictwo Uniwersytetu Gdańskiego, Gdańsk, 2012.

Van der Schaff, P., (2008) Public Real Estate Management Chalanges for Government, University Press, Delft:University Press;

Vermiglio, C., (2011) Public property management in Italian municipalities, Property Management, Vol. 29(5), 2011pp. 423-442.

Wartalska, M., (2004), Wybrane przestanki budowy programów zarządzania majątkiem komunalnym w aspekcie gospodarowania finansami miasta, [win:] Konkurencyjność i potencjał rozwoju polskich metropolii - szanse i bariery, Warsaw: Biuletyn KPZK PAN, bull. 214, Warsaw, 2004.

Wilczyński, W., (1965), Rachunek ekonomiczny a mechanizm rynkowy, Warsaw: PWE, Warsaw, 1965.

Wiszniewski, E., (1977), Ekonomika konsumpcji, PWN, Warsaw: PWN, $1977 .$.

Zielińska, A., (2013), Gospodarowanie na obszarach przyrodniczo cennych w Polsce w kontekście rozwoju zrównoważonego, Wrocław: Wydawnictwo UE we Wrocławiu, Wrocław, 2013. 